\title{
Granular cell tumour in male breast mimicking breast carcinoma
}

\author{
Frank Kuo, ${ }^{01}$ Kimberly Lally, ${ }^{2}$ Michael Lewis, ${ }^{3}$ Kiarash Vahidi ${ }^{4}$
}

${ }^{1}$ Department of Radiology, Ronald Reagan UCLA Medical Center, Los Angeles, California, USA

${ }^{2}$ Department of Pathology, Cedars-Sinai Health System, Los Angeles, California, USA ${ }^{3}$ Department of Pathology, VA Greater Los Angeles Healthcare System, Los Angeles, California, USA

${ }^{4}$ Department of Radiology, VA Greater Los Angeles Healthcare System, Los Angeles, California, USA

\section{Correspondence to}

Dr Kiarash Vahidi,

vahidi.kiarash@gmail.com

Accepted 14 February 2019

\section{DESCRIPTION}

Diagnostic mammography (figure 1A) demonstrated a $1.7 \mathrm{~cm}$ partially circumscribed, obscured mass in the left upper outer quadrant. Diagnostic ultrasound (figure 1B,C) showed a hypoechoic, parallel oval mass with areas of ill-defined margins. The breast mass was assigned a Breast Imaging-Reporting and Data System (BI-RADS) score of 4 and biopsy was recommended. Ultrasound-guided biopsy of the mass using a 14-gauge Bard biopsy device was successful (figure 1D). Initial microscopic diagnosis was granular cell tumour (GCT) (figure 2A,B) and follow-up immunohistochemistry showed tumour cells as strongly positive S-100 (figure 2C), CD-68 (figure 2D), and negative pancytokeratin and desmin (figure $2 \mathrm{E}, \mathrm{F}$ ) confirming the diagnosis of GCT. Even though the pathology was benign, surgical excision was recommended because of its suspicious imaging characteristics.

GCT is a benign neoplasm most commonly in the head and neck with breast accounting for $<10 \%$ of all GCTs. It is estimated that GCTs account for $1 / 1000$ cases of breast cancer. Its microscopic features and immunohistochemical profile of S-100 positive and cytokeratin negative favours a neural crest origin and it is assumed breast GCTs originate from peripheral nerves in the lobular breast tissue. ${ }^{1}$ GCTs stain positive for S-100, neuron specific enolase, CD68
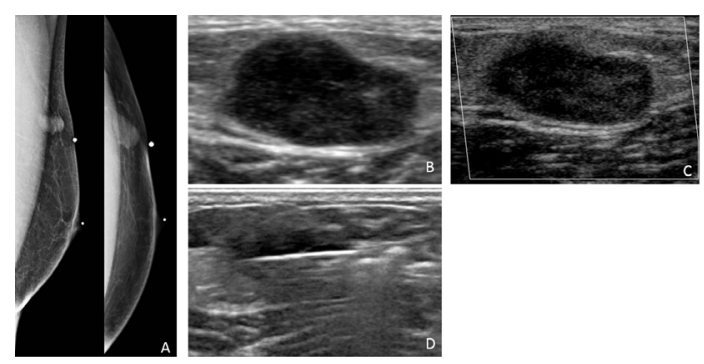

Figure 1 Diagnostic mammogram (A) with medial lateral oblique and craniocaudal views demonstrate $1.7 \mathrm{~cm}$ partially circumscribed, partially obscured mass in the left upper outer quadrant, against the pectoralis muscle. No suspicious calcifications, areas of architectural distortion or lymphadenopathy identified. Grey-scale (B) and colour Doppler (C) ultrasound at left breast one o'clock area $7 \mathrm{~cm}$ from the nipple shows a $1.8 \times 1.0 \times 1.4 \mathrm{~cm}$ hypoechoic, oval mass parallel to the skin surface with areas of ill-defined margins and no definite posterior acoustic enhancement or shadowing. No definite colour flow is seen with power Doppler. Successful biopsy (D) of the left breast mass using a 14-gauge Bard biopsy device.

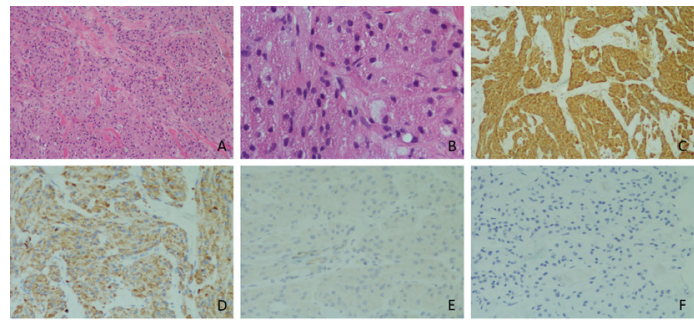

Figure 2 Histological sections of granular cell tumour of the breast. Low magnification (H\&E stain, $\times 100$ ) shows a moderately cellular tumour composed of infiltrating nests of polygonal cells with well-defined borders and intervening fibrous bands $(A)$. High magnification ( $H \& E$ stain, $\times 400$ ) shows tumour cells with small, oval, blandappearing nuclei and abundant granular eosinophilic cytoplasm (B). No nuclear atypia or mitotic figures are seen. Immunohistochemical staining for $\mathrm{S} 100$ (C) shows diffuse positivity in tumour cells at $\times 100$, positive staining for CD68 (D) and negative staining for cytokeratin (E) and desmin (F) at $\times 200$.

and CKI-C3; HMB45, cytokeratin, epithelial membrane antigen and desmin are consistently negative. ${ }^{2}$ Most GCTs are benign with insidious onset and slow growth. Approximately 1\%-2\% of GCTs can undergo malignant transformation with features suggesting malignancy including large mass at presentation, rapid growth, lymphadenopathy, poor borders and aggressive local invasion. $^{3}$

GCTs are most often felt as a firm mobile lump. Diagnostic workup of any palpable breast abnormality includes mammography and ultrasound. It is difficult to differentiate GCTs from malignant process on imaging due to their similarities. On mammography, GCTs can have features similar to primary carcinoma including irregularity, spiculation, stellation, isodensity and heterogeneity. On ultrasound, GCTs can have non-specific features including solid, hypoechoic, ill-defined mass, associated with posterior shadowing, or have a well-circumscribed oval mass, associated with posterior enhancement, depending on the extent of infiltration and degree of reactive fibrosis. Because of its similar imaging characteristic to a concerning mass, it is often assigned BI-RADS 4 and biopsy recommended.

The drastic difference in treatment and clinical course between GCT and malignant conditions such as breast carcinoma necessitates differentiation between the two. Treatment of GCT involves wide surgical excision which is generally curative though close observation is also acceptable. Incomplete 
excisions can cause local recurrence. GCTs of the breast does not pose a higher risk of developing breast cancer. If GCT undergoes malignant transformation, treatment approach is similar to other malignant breast masses with poor outcome and prognosis. ${ }^{3}$

\section{Learning points}

It is difficult to differentiate granular cell tumours (GCTs) from malignant process on both ultrasound and mammography due to its numerous similarities to breast malignancies.

- The drastic difference in treatment and clinical course between GCT and malignant conditions such as breast carcinoma necessitates differentiation between the two.

- Histopathological and immunohistochemical findings are essential for accurate diagnosis of GCT for proper treatment.
Contributors KV conceptualised the work. FK, KL, ML, KV made substantial contributions to the acquisition, analysis and interpretation of data for the work in addition to drafting, revising the manuscript. $\mathrm{KV}$ is responsible for the overall content as guarantor.

Funding The authors have not declared a specific grant for this research from any funding agency in the public, commercial or not-for-profit sectors.

Competing interests None declared.

Patient consent for publication Not required.

Provenance and peer review Not commissioned; externally peer reviewed.

\section{REFERENCES}

1. Goldblum JR, Folpe AL, Weiss SW. From Benign tumors of peripheral nerves. Enzinger and Weiss's soft tissue tumors. 6th ed. Philadelphia: Elsevier Saunders, 2014:784-854

2. Le BH, Boyer PJ, Lewis JE, et al. Granular cell tumor: immunohistochemical assessment of inhibin-alpha, protein gene product 9.5, S100 protein, CD68, and Ki-67 proliferative index with clinical correlation. Arch Pathol Lab Med 2004;128:771-5.

3. Fanburg-Smith JC, Meis-Kindblom JM, Fante R, et al. Malignant granular cell tumor of soft tissue: diagnostic criteria and clinicopathologic correlation. Am J Surg Pathol 1998;22:779-94.

Copyright 2019 BMJ Publishing Group. All rights reserved. For permission to reuse any of this content visit

https://www.bmj.com/company/products-services/rights-and-licensing/permissions/

BMJ Case Report Fellows may re-use this article for personal use and teaching without any further permission.

Become a Fellow of BMJ Case Reports today and you can:

- Submit as many cases as you like

- Enjoy fast sympathetic peer review and rapid publication of accepted articles

- Access all the published articles

Re-use any of the published material for personal use and teaching without further permission

For information on Institutional Fellowships contact consortiasales@bmjgroup.com

Visit casereports.bmj.com for more articles like this and to become a Fellow 